\title{
Water Resource Management, Quality and Climate Change in Nigeria
}

\author{
Fatemeh Nouban, Serah Onuh John and Nura Yunusa \\ Faculty of Civil and Environmental Engineering \\ Near East University, 99138 Nicosia (via Mersin 10, \\ Turkey), Cyprus.
}

\author{
Alkasim Aminu \\ Department of Electrical Engineering \\ Cyprus International University, 99138 Nicosia (via Mersin \\ 10, Turkey), Cyprus.
}

\author{
Zachariah Madaki \\ Department of Pharmacology \\ Near East University, 99138 Nicosia (via Mersin 10, Turkey), Cyprus.
}

\begin{abstract}
Nigeria is endowed with natural water resources abundantly, the country has substantial annual rainfall, large water bodies such as rivers, streams, lakes etc. and abundant groundwater reservoirs which are least developed and utilized which resulted in economic, social, environmental and health costs, such as a high rate of premature mortality and morbidity resulting from contamination of consumption, pollution of environmental and environmental resources, pollution and overexploitation of ground and surface water resources and low income and productivity. Therefore, enabling citizens with access to potable water is paramount. Although conjugate or integral water management or monitoring inhabited with limited studies even in Nigeria where over $57 \%$ of the population rely on groundwater source the management approaches is practically scanty while integral water use studied extensively, the study recognized the integrated water resources managements (IWRM), internationally recognized principles to support the effort of ensuring robust policy framework and appropriate investments in Nigeria's fresh water resources to enable the citizens with unlimited access to portable water.
\end{abstract}

Keywords:- Water Resources, Water Contamination, Water Shortage, Environmental Sustainability, Nigeria.

\section{INTRODUCTION}

Water is crucial for supporting livelihoods, improving standard of living and achieving sustainable development such as safeguarding health of the citizens, food and nutrition security provision, securing and ensures environmental sustainability, and promotes industrial and economic development [1-7]. However, the immensity of fresh water supply variability and fluctuation timing and durations are not predictable thereby causing unreliability of the resources thus posing great challenges to the water resources managers and to the citizens as a whole [8]. In addition to that, water quantity is water quality or pollution of water sources is also a major problems putting users and natural ecosystems at stakes. Although, some countries have taken a giant stride artificially to overcome the variability of natural water resources with supply-side infrastructure to ensure sustainable and reliable portable water supply, the supply-side solution alone viewed inadequate by the developed and least developed countries to address the demographic factors resulted in the increase in water demands, economy and climate pressures [8]. However, measures to counter the challenges of inadequate supply such as waste-water treatment and recycling, and management are being introduced [8] in form of Integrated Water Resources Management (IWRM) a Global Water Partnership [8] an empirical concept developed from practitioners' experience, is a process which promotes ecological friendly comprehensive initiatives of integrating multiple water sources and management to improve economy, standard of living in the country and maintaining the integrity of the natural environment [8].

Nigeria is endowed with natural water resources abundantly, the country has substantial annual rainfall, large water bodies such as rivers, streams, lakes etc. and abundant groundwater reservoirs which are least developed and utilized [9] to enable citizens with access to portable water by the relevant authorities. The inability to supply portable water to the urban, peri-urban, and rural areas have resulted in economic, social, environmental and health costs [10], such as a high rate of premature mortality and morbidity resulting from contamination of consumption, pollution of environmental and environmental resources, pollution and overexploitation of ground and surface water resources and low income and productivity [11-12]. This gap in Nigeria water demand is attributed to unsustainable initiative, lack of innovative approach and planning and development, and poor management and maintenance culture [13] thereby making the population to largely, about $60 \%$ to depend on groundwater sources [14-15] self-supply [16] which usually resulted to abuse and chaos if not properly planned and regulated [14, 16]. Furthermore, situations where residential settings and industries are close to each other as a result of improper town planning [17] hydrogeological state of the aquifer, geochemical retorts, lithology, soil-rock water boundaries, salt water intrusion, agricultural activities, inadvertent rural development, land use changes, inappropriate disposal and management of solid and liquid wastes, pumping groundwater, proximity and leaching of potential sinks such as poorly designed landfills, and drainage system and pit latrines [4, 18-27] have a great impact on groundwater quality [28-33] thus, putting human lives at stake [28]. While the major sources 
of drinking water are in rural or remoteness area consumed without treatment which have great impact on peoples' health are groundwater from shallow wells, springs and boreholes [34-35]. Contaminants in groundwater vary from one place to another and include different types of microorganisms, organic and inorganic substances, anions, cations, substantial metals and minerals [10]. However, studies have made known that the water in some wells in Nigeria is contaminated with chemicals and microbial with a negative impact on human health and the environment, respectively [35, 36-44]. Even though the water samples seem clean to the bare eye, chemical and mycobacterial analyzes suggest otherwise. Therefore, proper management of wastewater effluents, maintenance of water supply facilities and regular monitoring of water quality are essential to protect public health.

Furthermore, climate change such as increasing temperatures, varying rainfall, rising sea levels more frequent flooding, dearth and desertification, land degradation and extreme weather events in Nigeria have affected freshwater resources and loss of biodiversity [4547]. The increase in rainfall durations and intensities lead to the large runoffs and flooding in Nigeria [48]. The rainfall variation is expected to increase as a result of climate change which will lead to the increase of precipitation by approximately 5\%-20\% thus raising the sea levels thereby exacerbating flooding and coastal lands submersion [46, 49-50] while in Northern Nigeria drought becomes constant and expected to continue as result of rise in temperature and decline in precipitation [50-51] thereby Lake Chad and other lakes in the region are threatened to dry off with time $[45,52]$.

The Federal Ministry for the Environment [53] has predicted that the sea level will rise to around $0.1 \mathrm{~m}$ and 0.2 $\mathrm{m}$ by 2020 and 2050 respectively at low and $0.3 \mathrm{~m}$ and $1 \mathrm{~m}$ d 'by 2020 and 2050 high due to climate change. It is predicted that a sea level rise of around $1 \mathrm{~m}$ will cause part of the land in the Niger Delta to submerge [51, 53]. It was further estimated that a rise in sea level to around $95 \mathrm{~cm}$ by 2100 of submersion of coastal states such as Lagos and other small towns along the coast [46]. Inundation is also expected to occur in the northern region as a result of a decline in precipitation and temperature rising [51]. The impacts of climate change on water resources and hydrological systems in Nigeria is evident and expected to be adverse and extensive, and the environmental and socioeconomic problems that would be associated with the potential impacts may prove to be among the major problems facing the country. Therefore, the intent of this research is to extensively explore different Nigerian water resources potential and usage in order to help the relevant authorities in making inform-decision with essential and holistic integrated water resources management approach on the uncertainty creating by climate change about the future of Nigerian water availability, rainwater and surface water wastage and susceptibility to contamination, and demographic drive factors which made traditional fragmental water resources management approach in Nigeria no longer a viable option.minimum pit latrine design and sitting standard requirement for Northern Nigeria.

\section{INTEGRATED WATER RESOURCES MANAGEMENT}

Integrated Water Resources Management (IWRM), a Global Water Partnership [8] an empirical concept developed from practitioners' experience, is a process which promotes ecological friendly comprehensive initiatives of integrating multiple water sources and management to improve economy, standard of living in the country and maintaining the integrity of the natural environment [8]. The importance of IWRM is the conjunctive use and management of surface and groundwater [54] to meet the ever-increasing water demands of different water users, to address the problems of surface water scarcity, and to monitor and coordinate the use of both groundwater and surface water sources [55] because of the interconnectedness between the two systems. Therefore, both will enable the optimal groundwater and surface water use by improving water supply reliability water supply security enhancement and environmental sustainability [56-58].

Although, implementation of conjugative management approaches is practically scanty, efforts have been made to improve the South Chad Irrigation Project by implementing the groundwater recharge assessment and hydrological monitoring in Chad Basin [59]. Similar attempted have been made through the Orange-Senqu River Commission (ORASCOM) and Southern African Development Community (SADC) to manage the Stampriet Aquifer together with the basin's surface water [60]. However, many transboundary challenges and risks has been raised as a result of failure to take conjunctive approaches [55] such as recently discovered nitrate pollution by pit latrine Ramotswa Aquifer transboundary of Limpopo Basin where focused was mainly on surface water [61]. Groundwater abstraction for irrigation in Southern African rivers causes the river water to deplete is another challenge in Limpopo Basin thereby affecting Mozambique adversely [62]. Furthermore, the agricultural land salinization in Indus Basin caused by excessive abstraction of groundwater [63].

A lot of models (Table 1) has been developed to effectively allocate water resources as irrigation and increasing water demand and providing a decision support. 
ISSN No:-2456-2165

\begin{tabular}{|c|c|c|}
\hline Models & Purpose & Country \\
\hline Optimization models $[5,64]$ & $\begin{array}{l}\text { developed for cropping patterns and irrigation water } \\
\text { managements planning }\end{array}$ & \\
\hline $\begin{array}{l}\text { Single period inventory control } \\
\text { model }[65]\end{array}$ & $\begin{array}{l}\text { Combined use of groundwater and surface water for a } \\
\text { multiple storage system with a stochastic flow to the main } \\
\text { reservoir and the demand for irrigation water. }\end{array}$ & \\
\hline \multicolumn{3}{|l|}{$\begin{array}{l}\text { Conjunctive management model } \\
{[66]}\end{array}$} \\
\hline $\begin{array}{l}\text { Optimization model selection for } \\
\text { simulation-based programming } \\
\text { approaches [67] }\end{array}$ & $\begin{array}{l}\text { Planning and management of connective surface and } \\
\text { groundwater. }\end{array}$ & Iran \\
\hline $\begin{array}{l}\text { The use of a conjunctive macro- } \\
\text { level planning model [68] }\end{array}$ & Allocation of surface and groundwater in the delta regions & \\
\hline $\begin{array}{l}\text { Incorporated management model for } \\
\text { surface water and groundwater [69] }\end{array}$ & $\begin{array}{c}\text { To satisfy the demand of water in the urban areas of Jakarta } \\
\text { region }\end{array}$ & Indonesia \\
\hline Model of linear programming [70] & $\begin{array}{c}\text { For joint use of surface water and groundwater sources } \\
\text { management in the Sapon irrigation control area. The net } \\
\text { benefits of farming activities have been maximized given the } \\
\text { demand and supply of water }\end{array}$ & Indonesia \\
\hline $\begin{array}{c}\text { Integrated hydrological and } \\
\text { economic optimization model [71] }\end{array}$ & $\begin{array}{l}\text { Identify the optimal functioning of the water system and the } \\
\text { water allocation options to exploit the net economic benefits. }\end{array}$ & \\
\hline $\begin{array}{c}\text { Advanced linear programming } \\
\text { model [72] }\end{array}$ & $\begin{array}{c}\text { Optimizing the joint use of surface and groundwater for } \\
\text { irrigation development }\end{array}$ & Taiwan \\
\hline $\begin{array}{l}\text { Integrated multi-purpose planning } \\
\text { model [73] }\end{array}$ & $\begin{array}{l}\text { Conjunctive management of surface water and groundwater } \\
\text { in Taiwan by considering several objectives of simultaneous } \\
\text { minimization of fixed and operating costs }\end{array}$ & Taiwan \\
\hline $\begin{array}{l}\text { Nonlinear programming model tool } \\
\qquad[74]\end{array}$ & $\begin{array}{l}\text { Development of irrigation water through optimal distribution } \\
\text { of surface and groundwater to a maximum net benefits. }\end{array}$ & \\
\hline $\begin{array}{l}\text { Simulation-optimization method } \\
{[75]}\end{array}$ & Adequate utilization of surface and groundwater at basin level & Iran \\
\hline System dynamics [76] & $\begin{array}{c}\text { Surveying the performance of creating alternatives to the } \\
\text { common use of surface and groundwater, and assess the long- } \\
\text { term effects of these alternatives on reducing the risk of water } \\
\text { scarcity }\end{array}$ & \\
\hline $\begin{array}{l}\text { Developed a fuzzy inference system } \\
\text { [77] }\end{array}$ & $\begin{array}{c}\text { Conjunctive management of the use of surface and } \\
\text { groundwater by incorporating specialized knowledge and } \\
\text { operational policies into fuzzy rules }\end{array}$ & \\
\hline Simulation-optimization model [78] & $\begin{array}{l}\text { Utilizing the use of surface and groundwater in the } \\
\text { Zayandehrood river basin in Iran. The substitution models } \\
\text { were established using support vector machines to replace the } \\
\text { surface water and groundwater recreation models in the } \\
\text { optimization management model with the aim of minimizing } \\
\text { water scarcity to satisfy the 'irrigation }\end{array}$ & \\
\hline
\end{tabular}

Table 1:- Water Resource Conjugation Use

\section{RESULT NIGERIA WATER RESOURCES} POTENTIAL

\section{A. Rainfall}

Nigeria is a tropical climate, the northern region is semi-arid and rainier in the south. The rainy season is longer and more intense due to the African monsoon. The average annual rainfall is $1200 \mathrm{~mm}$ (47.2 in) for the whole country [79] (Figure 1). Over $80 \%$ of the rain, falls within the six wet months in the country, ranging from April to September every passing year [79] only negligible amount of this rain is utilized or provides Nigerians with a sources of portable water used for household activities which is usually collected from roofs of houses and kept in different storing systems. While the substantial amount rainwater percolated to the ground and the bulk amount however, flows as runoff into surface water bodies which is henceforth evaporated to the atmosphere through vegetation. An estimate of up to $76 \%$ of the rain that falls yearly in Nigeria, evaporates and leaves about $24 \%$ amount of both surface and subsurface runoffs [80]. 


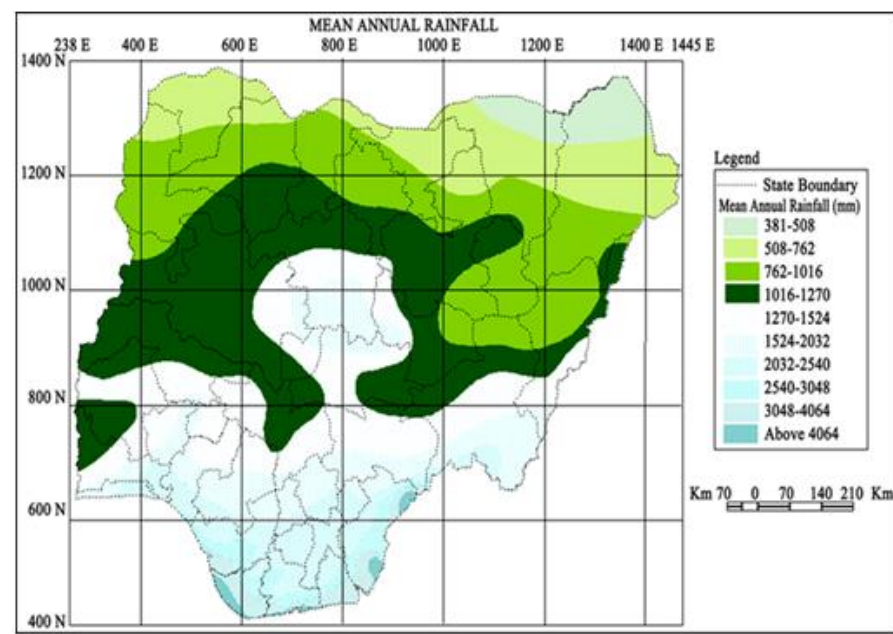

Fig 1:- Nigerian Average Annual Rainfall [81]

\section{B. Surface Sources}

Surface sources include the rivers, watercourses and canals, lagoons and tarns providing Web-based drainage basins nationwide (Figure 2) [79]. Major surface water sources are the two major Rivers, River Niger and River Benue including Cross River, Imo River, Sokoto Rivers, Ogun River, Anambra River, Kaduna Rivers, etc. however runoff quantities from basins varies which is depend on the factors such as rainfall intensity and intensity, climate and vegetation and topography [79]. About 320 billion cubic meters of freshwater are lost to the Atlantic Ocean annually by discharges from the two major rivers Niger and Benue [82].

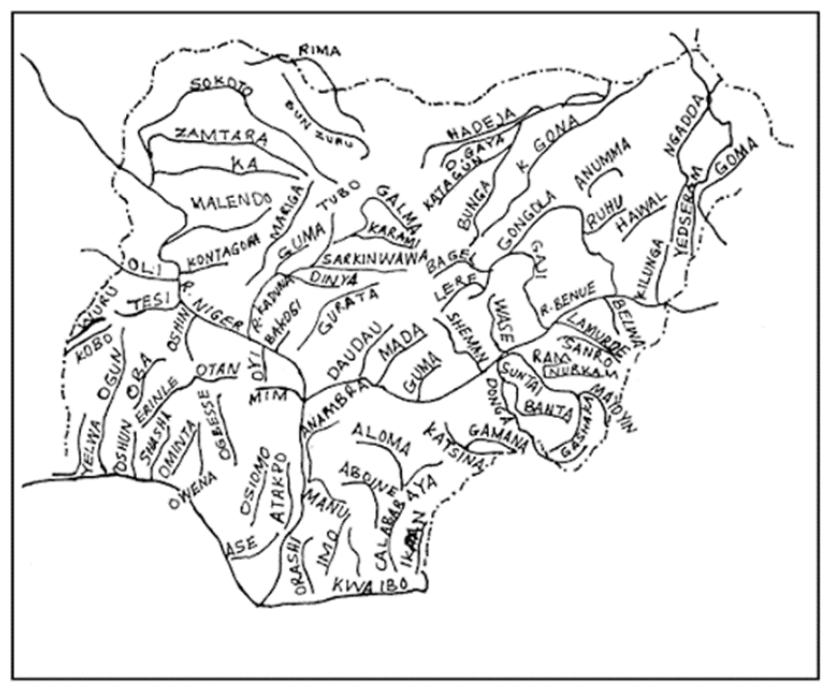

Fig 2:- Surface Water Distribution in Nigeria [83]

\section{Ground Water Resources}

Nigeria lies on two main rock formations widely distributed all over the country [79], the Basement Complex (precambrian and palaeozoic rocks, and jurassic granite) deposited in Jos area and postcambrian deposits (Sedimentary strata). The numerous groundwater reserves existing within these two geological formations [79] although the quantity varies however, estimated 30 times the surface water levels [84]. The Basement Complex is the main sources of tributary stream (headwaters) of a rivers and groundwater recharge zone [79] while sedimentary strata hypothetically contain both surface and ground water.

The sedimentary strata have both surface water and ground water of immense economic interest. The Basement Complex serves chiefly as a source for headwaters of various rivers and recharge ground water areas.

Nigeria is divided into nine distinctive hydrological provinces (Figure 3) Chad Basin, Iullemmeden Basin, Basement Complex areas, Benue Basin, Nsukka-Awgu, Aiyetoro-Ijebu Ode-Fugar, Ameki-Ogwashi-Asaba, Imo River Basin and Coastal Plains [85]. However, there are limited data on the Nigeria's groundwater reserves regarding the aquifers performance under pumping conditions in all Nigerian hydrological provinces except the Chad Basin province which studied extensively [86]. The country's rainfall helped in replenishing the groundwater levels despite huge reliance on it.

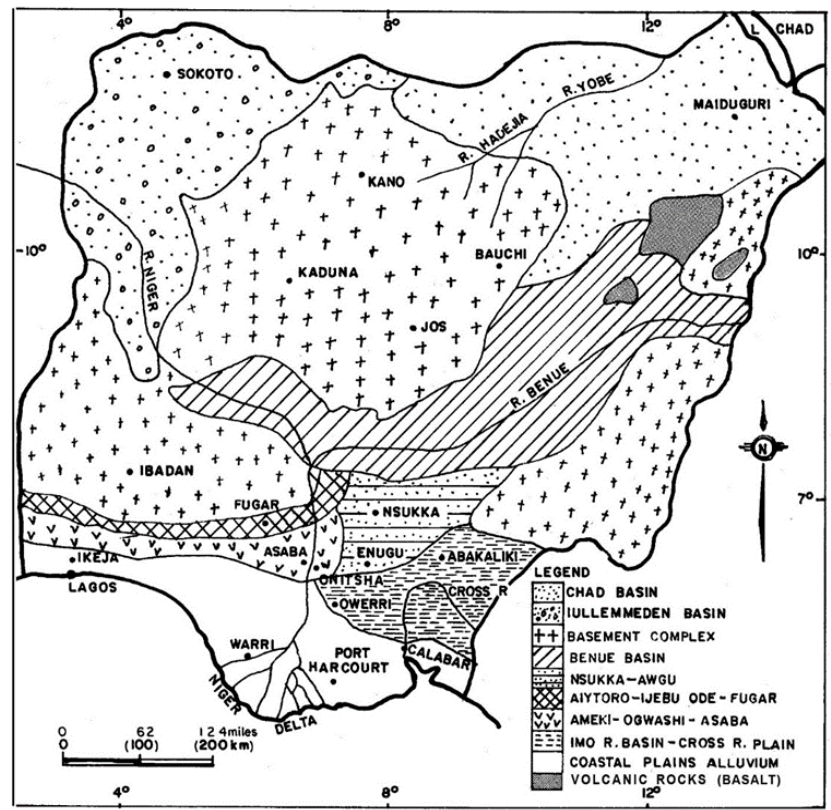

Fig 3:- Nigeria's Hydrological Provinces [85].

\section{DISCUSSION}

Nigeria's water usage varies from region to region, based on the 6 geopolitical zone according to the MICS 2016-17 [87] the water sources divided into two, improved and unimproved water sources. Improved water sources include pipped into dwelling and yard/compound/plot, and to neighbor and public tap/stand-piped, tube-well borehole, protected well, protected spring, rainwater collection, bottle water and satchet water while unimproved sources of water include unprotected well, unprotected spring, tanker truck, art with tank/drum, surface water, bottle water and satchet water and others (non-categorised). 


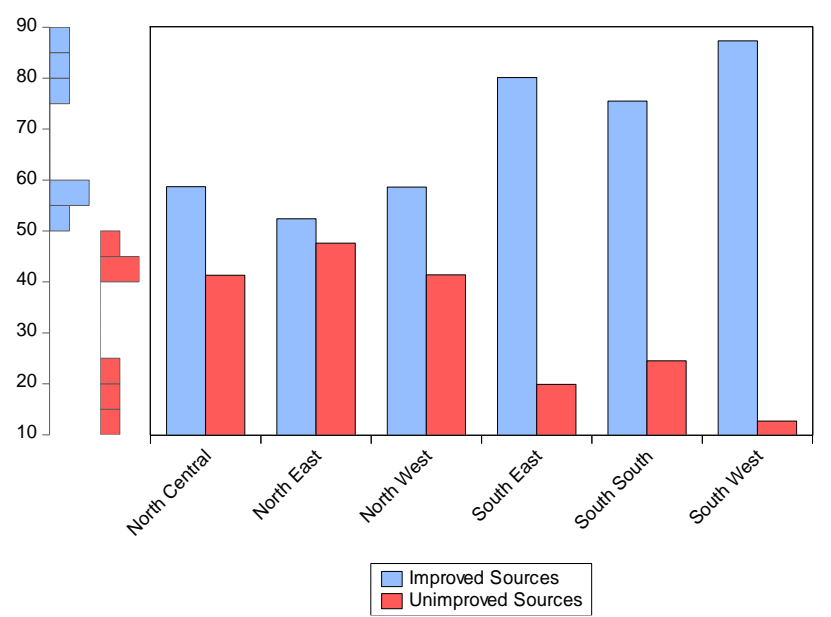

Fig 4:- Improved and Unimproved Water Sources in Nigeria

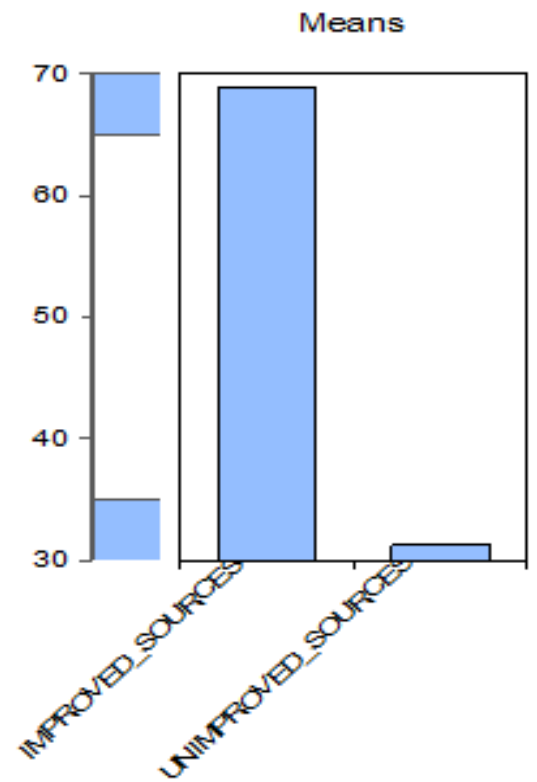

Fig 5:- Average Improved and Unimproved Water Sources

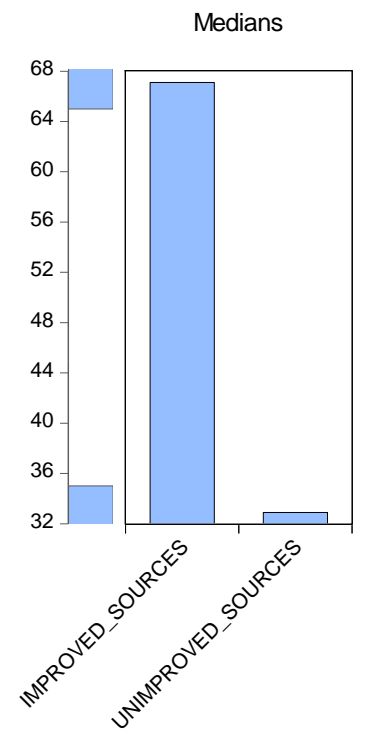

Fig 6:- Median Improved and Unimproved Water Sources

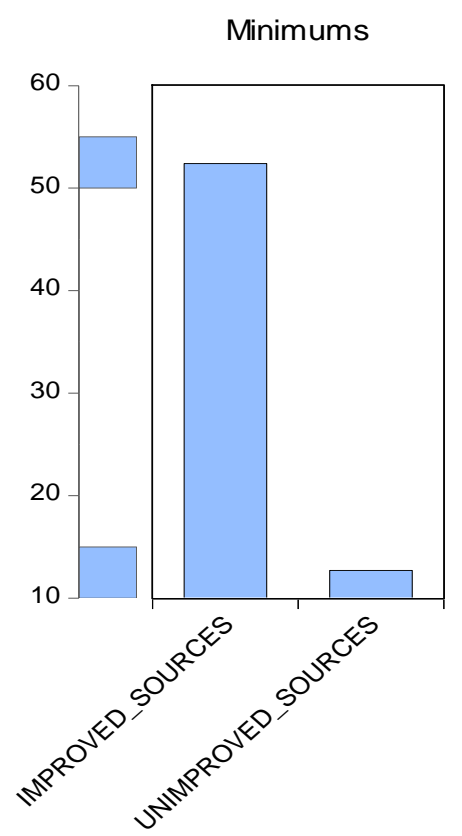

Fig 7:- Minimum Improved and Unimproved Water Sources

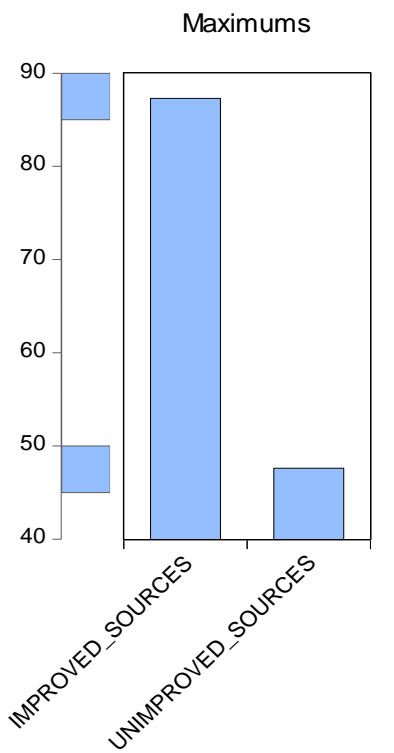

Fig 8:- Average Improved and Unimproved Water Sources

Water sources further grouped into main sources (Figure 9), surface water, groundwater, rainwater and other (unknown sources) (Table 2). 
ISSN No:-2456-2165

\begin{tabular}{|c|c|c|c|}
\hline Surface Water & Groundwater & Rainwater & Others \\
\hline $\begin{array}{c}\text { yard/compound/plot, and to neighbor and } \\
\text { public tap/ stand-piped. }\end{array}$ & $-\quad$ Tube-well borehole. & Unknown Sources \\
$-\quad \begin{array}{c}\text { Protected and unprotected spring. } \\
-\quad \text { Bottle water. }\end{array}$ & & \\
$-\quad$ Satchet water. & & & \\
$-\quad$ Tanker truck. & & & \\
$-\quad$ Cart with tank/drum. & & & \\
$-\quad$ Surface water & & & \\
\hline$\quad$ & & & \\
\hline
\end{tabular}

Table 2:- Main Water Sources

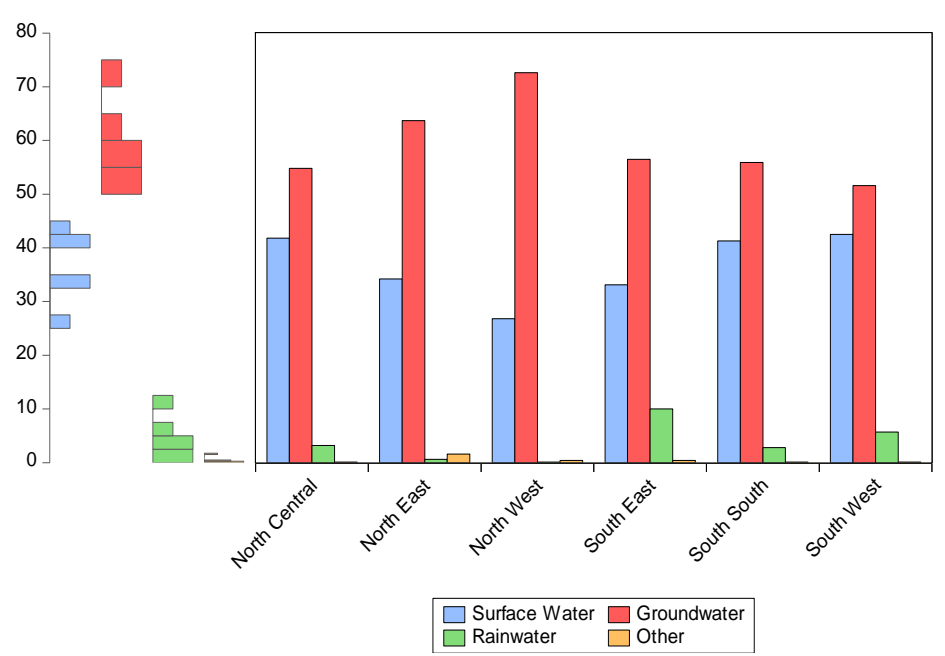

Fig 9:- Water Usage Variation by Main Sources in Nigeria

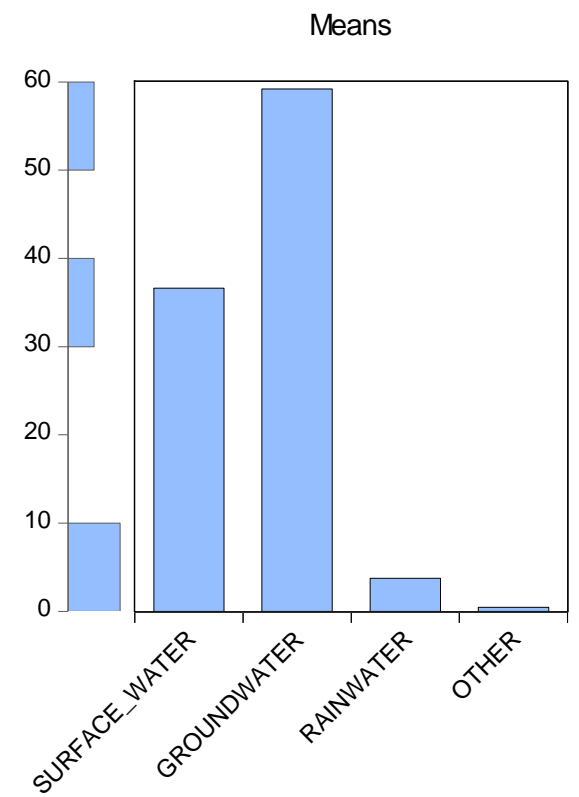

Fig 10:- Average Water Usage by Sources in Nigeria

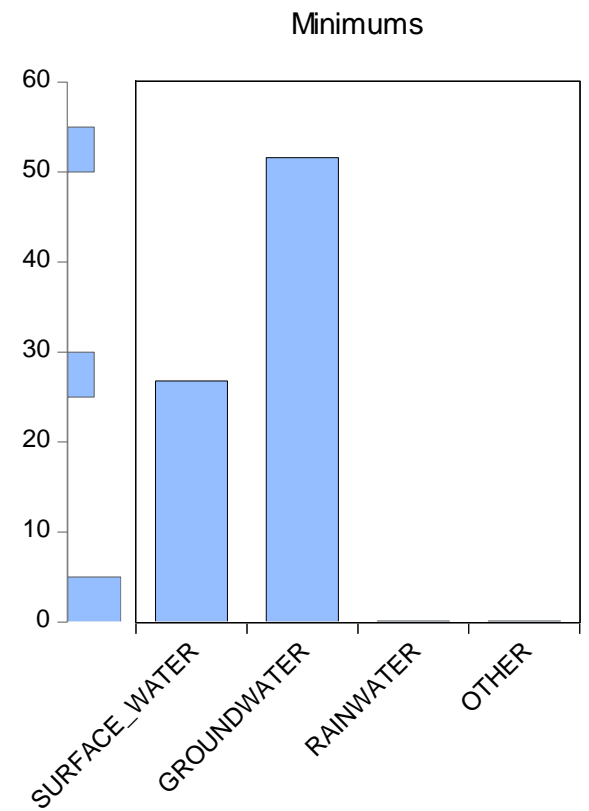

Fig 11:- Minimum Water Usage by Sources in Nigeria

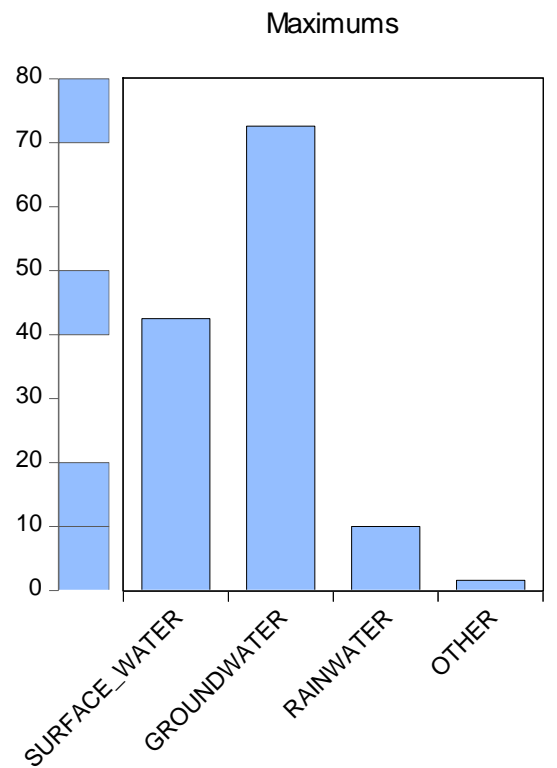

Fig 12:- Maximum Water Usage by Sources in Nigeria 


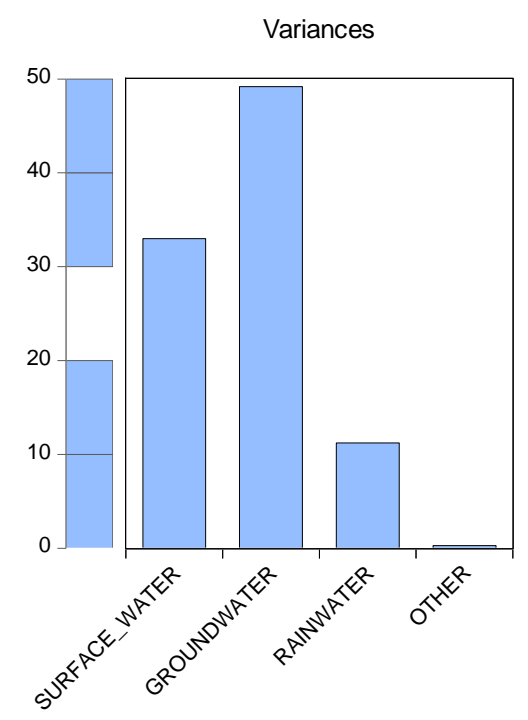

Fig 13:- Variance Water Usage by Sources in Nigeria

\section{DISCUSSION}

Water resources in Nigeria is abundant, the country endowed with several water sources such as rainfall, water bodies and groundwater reservoirs although there are great differences in water availability from region to region from far North to the tropical rainforests in the south. Although there are improve in access to improved water sources in the country, the study indicates that more than $66 \%$ of the population have access to improved water sources (Figure 5) there are regional unbalance in access to improved water, studies shows that three (3) geo-political zones access to improved water are below $60 \%$ and above $40 \%$ to the access of unimproved water while access in the south the access to improved water is above $70 \%$ and below $30 \%$ to the access to unimproved water sources (Figure 4).

Despite the uncertainty creating by climate changes in Northern region where the groundwater availability follows the irregular pattern of drought as a result of groundwater annual replenishment variation due to the raining season fluctuations, the region largely depends on groundwater sources especially Northwest where more than $70 \%$ of the people in the region rely on groundwater sources (Figure 9). Thus, an integrated water resources managements (IWRM) in forms of conjugative water resource monitoring and management recognized as robust effort in ensuring the appropriate investments in Nigeria's fresh water resources to enable the citizens with unlimited access to portable water.

Although conjugative water monitoring inhabited with limited studies which shows that the management approaches is practically scanty even in Nigeria where over $57 \%$ of the population rely on groundwater sources (Figure 10), the only study found in the region is that of lake Chad Basin conducted to improve the South Chad Irrigation Project by implementing the groundwater recharge assessment and Hydrological Monitoring [59]. Similar studies conducted in regards to conjugative management were attempted to manage the Stampiet Aquifers together with the basin's surface water [60]. Studies further shows that failure to consider conjugative approaches and groundwater abstraction for irrigation in Limpopo Basin Southern African causes many transboundary challenges and risks [61] South African rivers depletion [62]. While conjugative water use is widely and extensively studied and several models have been developed (Table 2) for the integrated water use for different purposes.

\section{CONCLUSION}

The variability of water supply over a time as a result of seasonal fluctuations and regional unbalance, the great water resources potential, and demographic and climatic changes driving factors further increase the stress on water resources made the traditional fragmented approaches no longer viable and a more holistic approach to water management is essential. Thus, governmental and private sector need to make an inform decision and adaptive strategies on Nigerian water resource management and apportion of diminishing water supplies between everincreasing demands. Therefore, this study recognized the integrated water resources managements (IWRM), internationally recognized principles to support the effort of ensuring robust policy framework and appropriate investments in Nigeria's fresh water resources to enable the citizens with unlimited access to portable water.

Adopting an integrated water management framework may benefit both the decision makers and planners to develop a more accurate and practical policy for water management. Therefore, studies have shown a detailed information, addressing the problems earlier mentioned in developing an imperative conjunctive water management in Nigeria and to outline the pathways toward practical implementations in order to unlock the potential of conjugative management and use approach in Nigeria's water resources management.

\section{REFERENCES}

[1]. Dinka, M. O., Loiskandl, W., \& Ndambuki, J. M. (2015). Hydrochemical characterization of various surface water and groundwater resources available in Matahara areas, Fantella region of Oromiya region. Journal of Hydrology: Regional Studies, 3, 444-456.

[2]. Falkenmark, M. (2015). Adapting to climate change: towards societal water insecurity in dry-climate countries'. International Journal of Water Resources Development, 25(2), 123-136.

[3]. Gwenzi, W., Dunjana, N., Pisa, C., Tauro, T., \& Nyamadzawo, G. (2015). Water quality and public health risks associated with roof rainwater harvesting systems for potable supply: review and perspectives. Water Quality Ecology. doi:10.1016/j. swaqe2015.01.006.

[4]. Huang, W. J., Chen, W.-Y., Chuang, Y.-H., Lin, Y.H., \& Chen, H.- W. (2014). Biological toxicity of groundwater in a seashore area: causal analysis and its spatial pollutant pattern. Chemosphere, 100, 8-15. 
[5]. Sethi, L., Kumar, D. N., Panda, S., and Mal, B. (2002). Optimal crop planning and conjunctive use of water resources in a coastal river basin. Water Resour. Manag. 16, 145-169. doi: 10.1023/A:1016137726131

[6]. Mayzelle, M. M., Viers, J. H., Medellin-Azuara, J., \& Harter, T. (2015). Economic feasibility of irrigated agricultural land use buffers to reduce groundwater nitrate in rural drinking water sources. Water, 17, 1237.

[7]. Sobowale, A., Ramalan, A. A., Mudiare, O. J., \& Oyebode, M. A. (2015). Groundwater recharge studies in irrigated lands in Nigeria: implications for basin sustainability. Sustainability Water Quality Ecology. doi:10.1016/j.swaqe.2014.12.004.

[8]. Integrated Water Resources Management in Eastern Europe, the Caucasus and Central Asia. (2014). Organisation for Economic Co-operation and Development (OECD), United Nations Economic Commission for Europe (UNECE).

[9]. G. U. Ojiako. (2009). Nigerian Water Resources and Their Management. Water International.

[10]. Adebayo Olatunbosun Sojobi. (2016). Evaluation of groundwater quality in a rural community in North Central of Nigeria. Environ Monit Assess 188: 192.

[11]. Sojobi, A. O., Owamah, H. I., \& Dahunsi, S. O. (2014). Comparative study of household water treatment in a rural community in Kwara State Nigeria. Nigerian Journal of Technology, 33(1), 134140.

[12]. Tortajada, C. (2002). Water infrastructure as an essential element for human development. International Journal of Water Resources Development, 30(1), 8-19.

[13]. Oyegoke, S. O., Adeyemi, A. O., \& Sojobi, A. O. (2012). The challenges of water supply for a megacity: a case study of Lagos Metropolis. International Journal of Scientific and Engineering Research, 3(2), 1-10.

[14]. D.O. Omole, "Sustainable Groundwater Exploitation in Nigeria," Journal of Water Resources and Ocean Science, vol. 2(2), pp. 9-14, 2013.

[15]. D.O. Omole, Reaeration Coef icient Modelling: Case study of River Atuwara, Ota, Nigeria, LAP Lambert Academic Publishing GmbH \& Co. KG, Saarbrücken, Germany, 2011.

[16]. D.O. Omole and J.M. Ndambuki, "Nigeria's Legal Instruments for Land and Water Use: Implications for National Development," in E. Osabuohien (ed.), InCountry Determinants and Implications of Foreign Land Acquisitions, pp. 354-373, IGI GLOBAL, Hershey, PA, USA: Business Science Reference, 2015. DOI: 10.4018/978-1-4666-7405-9.ch018.

[17]. D.O. Omole and S.A. Isiorho, "Waste Management and Water Quality Issues in Coastal States of Nigeria: The Ogun State Experience," Journal of Sustainable Development in Africa, vol. 13(6), pp. 207- 217, 2011.

[18]. Akhtar, M. M., Tang, Z., \& Mohamadi, B. (2014). Contamination potential assessment of potable groundwater in Lahore. Polish Journal of Environmental Studies, 23(6), 1095-1916.
[19]. Al-ahmadi, M. E., \& El-Fiky, A. A. (2009). Hydrogeochemical evaluation of shallow alluvial aquifer of Wadi Marwani, western Saudi Arabia. Journal of King Saudi University, 21, 179-190.

[20]. Kumar, P., Bansod, B. K. S., Debnath, S. K., Thakur, P. K., \& Ghashyam, C. (2015). Index-based groundwater vulnerability mapping models using hydrogeological settings: a critical evaluation. Environmental Impact Assessment Review, 51, 3849.

[21]. Oni, A. A., \& Hassan, A. T. (2013). Groundwater quality in the vicinity of Aba-Eku dumpsite, Ibadan, Southwest, Nigeria. A detailed report. Ethiopian Journal of Environmental Studies and Management, 6(6), 589-600.

[22]. Oyelami, A. C., Aladejana, J. A., \& Agbede, O. O. (2013). Assessment of the impact of open waste dumpsites on groundwater quality: a case study of the Onibu-Eja dumpsite, Southwestern Nigeria. Procedia Earth and Planetary Science, 7, 648-651.

[23]. Vasanthaviger, M., Srinivasamoorthy, K., \& Prasanna, M. V. (2013). Identification of groundwater contamination zones and its sources by using multivariate statistical approach in Thirumanimuthar sub-basin, Tamil Nadu, India. Environmental Earth Science, 68, 1783-1795.

[24]. Porowska, D. (2014). Assessment of groundwater contamination around reclaimed municipal landfillOtwock area, Poland. Journal of Ecological Engineering, 15(4), 69-81.

[25]. Rao, N. S. (2014). Spatial control of groundwater contamination using principal component analysis. Journal of Earth System Science, 123(4), 715-728.

[26]. Srinivas, Y., Muthuraj, D., Oliver, D. H., Raj, A. S., \& Chandrasekar, N. (2013). Environmental applications of geophysical methods to map groundwater quality at Tuticorin, Tamilnadu, India. Environmental Earth Science, 70, 2143-2152.

[27]. Wanke, H., Nwakfila, A., Hamutoko, J. T., Lohe, C., Nembo, F., Petrus, I., David, A., Beukes, H., Masule, N., \& Quinger, M. (2015). Hand dug wells in Namibia: an underestimated water source or a threat to human health? Journal of Physical Chemistry. doi:10.1016/j.pce.2015.01.004.

[28]. I.K. Adewumi, A.S. Ogbiye, E.O. Longe, and D.O. Omole, "Effect of industrial effluents on water quality of River Atuwara in Ota, Nigeria," in Adeyemo, R. (ed.), Urban Agriculture, Cities and Climate Change, Cuvallier Verlag, Gottingen, Germany, ISBN: 978-386955-813-4: 272-280, 2011.

[29]. P.D. Glynn and L.N. Plummer, "Geochemistry and the understanding of ground-water systems," Hydrogeology Journal, vol. 13(1), pp. 263-287. 2005

[30]. C.E. Egboka, G.I. Nwankwor, I.P. Orajaka, and A.O. Ejiofor, "Principles and problems of environmental pollution of groundwater resources with case examples from developing countries," Environmental Health Perspectives, vol. 83, pp. 39-68,1989.

[31]. A.A.A. Kayode, J.O. Babayemi, E.O. Abam, and O.T. Kayode, "Occurrence and health implications of high concentrations of Cadmium and Arsenic in drinking 
water sources in selected towns of Ogun State, South West, Nigeria," Journal of Toxicology and Environmental Health Sciences, vol. 3(15), pp. 385391, 2011.

[32]. O.O. Ajayi, D.O. Omole, and C.P. Emenike, "Use of Agricultural Wastes and Limestone for the Removal of Iron from Drinking Water," 3 rd International Conference on African Development Issues (CUICADI 2016), pp. 69-71, 2016.

[33]. S.N. Chinedu, O.C. Nwinyi, A.Y. Oluwadamisi, and V.N. Eze, "Assessment of water quality in Canaanland, Ota, Southwest Nigeria," Agriculture and Biology Journal of North America, vol. 2(4), pp. 577 583, 2011.

[34]. NBS/UNICEF/UNFPA Joint Report (2011). Nigeria multiple indicator cluster survey [internet]. c2011 [cited 2015 April 20]. Available from www.nigerianstat.gov.ng/pages/download/ 145

[35]. Dwairo, B., Hoko, Z., Love, D., \& Guzha, E. (2006). Assessment of the impacts of pit latrines on groundwater quality in rural areas: a case study from Marondera district of Zimbabwe. Physics and Chemistry of the Earth, 31, 779-788.

[36]. Feachem RG, Bradley DJ, Garelick H, Mara DD. Sanitation and Disease: Health Aspects of Excreta and Wastewater Management. New York: John Wiley \& Sons Ltd. 1983

[37]. Jay P. Graham and Matthew L. Polizzotto. Pit Latrines and Their Impacts on Groundwater Quality: A Systematic Review. Environmental Health Perspectives. 2013, 121(5).

[38]. Pujari PR, Padmakar C, Labhasetwar PK, Mahore P, Ganguly AK.. Assessment of the impact of on-site sanitation systems on groundwater pollution in two diverse geological settings--a case study from India. Environ Monit Assess. 2012, 184(1), 251-63.

[39]. Vinger B, Hlophe M, Selvaratnam M. Relationship between nitrogenous pollution of borehole waters and distances separating them from pit latrines and fertilized fields. Life Sci J. . 2019, 9(1), 402-407.

[40]. Banerjee G. Underground pollution travel from leach pits of on-site sanitation facilities: a case study. Clean Technol Environ Policy. 2011, 13(3), 489-497

[41]. Verheyen J, Timmen-Wego M, Laudien R, Boussaad I, Sen S, Koc A, Uesbeck A, Mazou F, Pfister H. Detection of adenoviruses and rotaviruses in drinking water sources used in rural areas of Benin, West Africa. Appl Environ Microbiol. 2009, 75(9), 2798801.

[42]. Ophori, D. Groundwater Quality in Shallow Domestic Water Wells, Ughelli, Nigeria. 2006, Retrieved December 2, 2019, from http://www.iseg.giees.uncc.edu/abuja2006/Abstracts/ Abstract_ID_284.

[43]. Zingoni E, Love D, Magadza C, Moyce W, Musiwa K. Effects of a semi-formal urban settlement on groundwater quality Epworth (Zimbabwe): case study and groundwater quality zoning. Phys Chem Earth. 2005, 30(11-16), 680-688.
[44]. Adelana, S. M. A. \& Olasehinde, P. I. High nitrate in water supply in Nigeria: implications for human health. Water Resources. 2003, 14, 1-11.

[45]. Ebele, N. E. and Emodi, N. V. (2016). Climate change and its impact in Nigerian economy. Journal of Scientific Research \& Reports, 10(6), 1-13. http://www.journaljsrr.com/index.php/JSRR/article/vi ew/21917/40737

[46]. Elisha, I. et al. (2017). Evidence of climate change and adaptation strategies among grain farmers in Sokoto State, Nigeria. IOSR Journal of Environmental Science, Toxicology and Food Technology (IOSRJESTFT), 11(3), 1-7. http://www.iosrjournals.org/iosrjestft/papers/vol11issue\%203/Version2/A1103020107.pdf

[47]. Olaniyi, O. A. et al. (2013). Review of climate change and its effect on Nigeria ecosystem. International Journal of African and Asian Studies, 1, 57. https://pdfs.semanticscholar.org/f9bd/9c18dfb45724a2 a946a3854c756e62ad9f6b.pdf

[48]. Enete IC (2014). Impacts of climate change on agricultural production in Enugu State, Nigeria. Journal of Earth Science \& Climatic Change, 5(9), 234.

https://www.omicsonline.org/openaccess/impacts-ofclimate-change-on-agricultural-production-in-enugustate-nigeria-2157-7617.1000234.php?aid=32633

[49]. Akande, A. et al., (2017). Geospatial Analysis of Extreme Weather Events in Nigeria (1985- 2015) Using Self-Organizing Maps. Advances in Meteorology. https://doi.org/10.1155/2017/8576150

[50]. Olapido, E. (2010). Towards enhancing the adaptive capacity of Nigeria: a review of the country's state of preparedness for climate change adaptation. Heinrich Böll Foundation Nigeria. https://ng.boell.org/sites/default/files/uploads/2013/10 /nigeria_prof_oladipo_final_cga_study.pdf

[51]. Amanchukwu, R. N. et al. (2015). Climate change education in Nigeria: The role of curriculum review. Education, 5(3): 71-79. https://www.researchgate.net/profile/Nwachukwu_Pri nce_Ololube/publication/283081778_Climate_Change _Education_in_Nigeria_The_Role_of_Curriculum_Re view/links/56292c5508ae518e34 7c967b/ClimateChange-Education-in-Nigeria-The-Role-ofCurriculum-Review.pdf

[52]. Dioha, M. O. and Emodi, N. V. (2018). Energyclimate dilemma in Nigeria: Options for the future. IAEE Energy Forum. https://www.google.com/url?sa=t\&rct=j\&q=\&esrc=s \&source=web\&cd=108\&ved=2ahUKEwihv4iA27kAh Voc98KHWNKDtw4MhAWMDI6BAgQEAI\&url=ht tps\%3A\%2F\%2Fwww.iaee.org\%2Fen\%2Fpublication s\%2Fnewsletterdl.aspx\%3Fid\%3D465\&usg=AOvVa w3qHlxFJnRFCXox9HBg4d-I

[53]. Federal Ministry of Environment (2014). United Nations Climate Change Nigeria. National Communication (NC). NC 2. 2014. https://unfccc.int/sites/default/files/resource/nganc2.p df 
[54]. Zhang X (2015) Conjunctive surface water and groundwater management under climate change. Front. Environ. Sci. 3:59. doi: 10.3389/fenvs.2015.00059.

[55]. Jonathan Lautze, Bunyod Holmatov, Davison Saruchera and Karen G. Villholth. (2018). Conjunctive management of surface and groundwater in transboundary watercourses: a first assessment. Water Policy 20:1-20.

[56]. Blomquist, W., Heikkila, T. \& Schlager, E. (2001). Institutions and conjunctive water management among three western states. Natural Resources Journal 41, 653-683.

[57]. Dudley, T. \& Fulton, A. (2006). Conjunctive Water Management: What is it? Why Consider it? What are the Challenges? Agriculture and Natural Resources. Oakland University of California, CA, USA.

[58]. World Bank (2005). Shaping the Future of Water for Agriculture: A Sourcebook for Investment in Agricultural Water Management. Agricultural and Rural Development. The International Bank for Reconstruction and Development/The World Bank, Washington, DC, USA

[59]. Isiorho, S. A., Oguntola, J. A. \& Olojoba, A. (2000). Conjunctive water use as a solution to sustainable economic development in Lake Chad Basin, Africa. In: 10th World Water Congress: Water, the World's Most Important Resource. International Water Resources Association, Melbourne, Australia, p. 330.

[60]. Ross, A. (2015). The Governance Of Transboundary Aquifers: Towards A Multicountry Consultation Mechanism, The Case Of The Stampriet Aquifer. XVth World Water Congress, 25-29 May, Edinburgh, Scotland. Available at: http://www.iwra.org/ index.php?page=286\&abstract_id=2954 (accessed 29 July 2016).

[61]. Abiye, T. (2012). Groundwater Needs Assessment; ORASECOM. African Groundwater Network, Febraury 2012. Available at: http://www.splashera.net/downloads/groundwater/1_ORASECOM_final _report.pdf.

[62]. Owen, R. (2011). Groundwater Needs Assessment. Limpopo Basin Commission, LIMCOM. AGW-Net. http://splash-era.net/

downloads/groundwater/2_LIMCOM_final_report.pdf

[63]. International Union for the Conservation of Nature (IUCN) (2013). Beyond Indus Water Treaty: Water Cooperation for Managing Groundwater Environments - Policy Issues and Options. Karachi, Pakistan. Available at: https://cmsdata.iucn.org (accessed 1 July 2016).

[64]. Vedula, S., Mujumdar, P. P., and Chandra Sekhar, G. (2005). Conjunctive use modeling for multicrop irrigation. Agric. Water Manag. 73, 193-221. doi: 10.1016/j.agwat.2004.10.014

[65]. Azaiez, M. N. (2002). A model for conjunctive use of ground and surface water with opportunity costs. Eur. J. Oper. Res. 143, 611-624. doi: $10.1016 / \mathrm{S} 03772217(01) 00339-3$
[66]. Barlow, P., Ahlfeld, D., and Dickerman, D. (2003). Conjunctive-management models for sustained yield of stream-aquifer systems. J. Water Resour. Plan. Manag. 129, 35-48. doi: 10.1061/(ASCE)07339496(2003)129:1(35)

[67]. Karamouz, M., Kerachian, R., and Zahraie, B. (2004). Monthly water resources and irrigation planning: case study of conjunctive use of surface and groundwater resources. J. Irrig. Drain. Eng. 130, 391-402. doi: 10.1061/(ASCE)07339437(2004)130:5(391).

[68]. Rao, S., Bhallamudi, S., Thandaveswara, B., and Mishra, G. (2004). Conjunctive use of surface and groundwater for coastal and deltaic systems. J. Water Resour. Plan. Manag. 130, 255-267. doi: 10.1061/(ASCE)0733-9496(2004) 130:3(255).

[69]. Syaukat, Y., and Fox, G. C. (2004). Conjunctive surface and ground water management In the Jakarta Region, Indonesia. J. Am. Water Resour. Assoc. 40, 241-250. doi: 10.1111/j.1752-1688.2004.tb01022.x.

[70]. Khare, D., Jat, M. K., and Ediwahyunan. (2006). Assessment of counjunctive use planning options: a case study of Sapon irrigation command area of Indonesia. J. Hydrol. 328, 764-777. doi: 10.1016/j.jhydrol.2006.01.018

[71]. Pulido-Velázquez, M., Andreu, J., and Sahuquillo, A. (2006). Economic optimization of conjunctive use of surface water and groundwater at the basin scale. J. Water Resour. Plan. Manag. 132, 454-467. doi: 10.1061/(ASCE)07339496(2006)132:6(454).

[72]. Cheng, Y., Lee, C.H., Tan, Y.C., andYeh,H.F. (2009). An optimal water allocation for an irrigation district in Pingtung County, Taiwan. Irrig. Drain. 58, 287-306. doi: 10.1002/ird.411.

[73]. Yang, C.-C., Chang, L.-C., Chen, C.-S., and Yeh, M.S. (2009). Multi-objective planning for conjunctive use of surface and subsurface water using genetic algorithm and dynamics programming. Water Resour. Manag. 23,417-43. doi: 10.1007/s11269-008-9281-5

[74]. Montazar, A., Riazi, H., and Behbahani, S. (2010). Conjunctive water use planning in an irrigation command area. Water Resour. Manag. 24, 577-596. doi: 10.1007/s11269-009-9460-Z

[75]. Safavi, H., Darzi, F., and Mariño, M. (2010). Simulation-optimization modeling of conjunctive use of surface water and groundwater. Water Resour. Manag. 24, 1965-1988. doi: 10.1007/s11269-0099533-z.

[76]. Chang, L.-C., Chu, H.-J., and Chen, Y.-W. (2013). A fuzzy inference system for the conjunctive use of surface and subsurface water. Adv. Fuzzy Syst. 2013:128393. doi: 10.1155/2013/128393.

[77]. Chang, L.-C., Ho, C.-C., Yeh, M.-S., and Yang, C.-C. (2011). An integrating approach for conjunctive-use planning of surface and subsurface water system. Water Resour. Manag. 25, 59-78. doi: 10.1007/s11269-010-9687-8.

[78]. Safavi, H., and Esmikhani, M. (2013). Conjunctive use of surface water and groundwater: application of support vector machines (SVMs) and genetic algorithms. Water Resour. Manag. 27, 2623-2644. doi: 10.1007/s11269-0130307-2. 
[79]. G. U. Ojiako (1985) Nigerian Water Resources and Their Management, Water International, 10:2, 64-72, DOI: $10.1080 / 02508068508686310$.

[80]. Ayoade, J. O., Water resources and their development in Nigeria, Hydrological Science Bulletin, XX (1975) 581-591.

[81]. Hassan T. Ishaku and M. Rafee Majid. (2010). XRaying Rainfall Pattern and Variability in Northeastern Nigeria: Impacts on Access to Water Supply. Journal of Water Resource and Protection 02(11):952-959. DOI: 10.4236/jwarp.2010.211113.

[82]. Obasi, G. 0. P., Water balance in Nigeria, Quarterly Meteorological Magazine, June 1972, Vol. 2, The Nigeria Meteorological Service, Lagos.

[83]. J.B.E. Awachie. Perspectives, Prospects, Planning and Problems in River Basin Management and Development/Perspectives, Avenir, Planification et Problemes en Matiere D'amenagement et De la Mise en Valeur des Bassins Hydrographiques. Retrieved May 15, 2020 from http://www.fao.org/3/AD793B01.htm.

[84]. Oyebande, L., On the argumentation of irrigation water supply from ground water sources in the North Central Areas of Nigeria, Proc. 4th Afro-Regional Conference, International Conference on Irrigation and Drainage, Lagos, 1982, Vol. I,

[85]. Egboka, B. C. E., The Hydrogeological Provinces of Nigeria, Department of Geology, University of Nigeria, Nsukka, unpublished paper, 1981.

[86]. Ifedigbo, C. and Joseph, A., Harnessing water resources for agriculture etc., Nigeria Review, No. 14, 1979.

[87]. National Survey Finding Report. (2018). The fifth round Multiple Indicator Cluster Survey (MICS5), Multiple Indicator Cluster Survey 2016-17. 